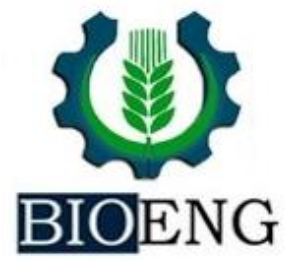

\title{
ASPECTOS QUALITATIVOS DA ÁGUA SUBTERRÂNEA DE POÇOS TUBULARES EM CAMPO GRANDE - MS
}

\author{
J. M. Cardoso ${ }^{1}$, J. M. M. Bega ${ }^{2 *}$, J. N. de Oliveira ${ }^{3}$, J. H. P. \\ Américo-Pinheiro 4
}

\begin{abstract}
${ }^{1}$ Instituto de Meio Ambiente de Mato Grosso do Sul-IMASUL, Campo Grande - MS, Brasil
${ }^{2}$ Faculdade de Engenharia de Ilha Solteira - FEIS, Unesp Câmpus de Ilha Solteira - SP, Brasil

${ }^{3}$ Faculdade de Engenharia de Ilha Solteira - FEIS, Unesp Câmpus de Ilha Solteira - SP, Brasil

${ }^{4}$ Universidade Brasil, Fernandópolis - SP, Brasil
\end{abstract}

Article history: Received 06 March 2020; Received in revised form 24 March 2020; Accepted 24 March 2020; Available online 30 June 2020.

\section{RESUMO}

O presente trabalho teve como objetivo avaliar a qualidade da água subterrânea outorgada do município de Campo Grande - MS, mais precisamente os seguintes parâmetros: potencial hidrogeniônico, turbidez, nitrato, nitrito, sulfato e coliformes termotolerantes. Para tanto, utilizou-se como fonte dos dados o Sistema IMASUL (Instituto de Meio Ambiente de Mato Grosso do Sul) de Registros e Informações Estratégicas do Meio Ambiente, pelo qual se realiza todo o procedimento de solicitação e análise de outorga. Foram criados mapas de interpolação pelo método da Ponderação de Distância Inversa (IDW), o qual utiliza valores conhecidos para estimar valores desconhecidos para melhor representar espacialmente a possível concentração dos parâmetros analisados. Alguns parâmetros apresentaram alterações que variaram de acordo com a localização dos poços, zona rural ou urbana, como a concentração de nitrato na água de seis poços correspondente a teores acima de $10 \mathrm{mg} / \mathrm{L}$. De modo geral, segundo a Resolução CONAMA n 396 de 2008, para os parâmetros avaliados, considera-se a água de Campo Grande de boa qualidade para uso recreativo e de qualidade relativamente boa para o consumo humano, pois há parâmetros em desacordo com a Portaria de Consolidação nº 5 de 2017.

Palavras-chave: recursos hídricos, hidrogeologia, poluição urbana

\section{QUALITATIVE ASPECTS OF GROUNDWATER IN TUBULAR WELLS IN CAMPO GRANDE - MS}

\begin{abstract}
This work aimed to evaluate the quality of groundwater granted in the municipality of Campo Grande - MS, more precisely the parameters: hydrogen potential, turbidity, nitrate, nitrite, sulfate and thermotolerant coliforms. For that, the IMASUL (Instituto de Meio Ambiente de Mato Grosso do Sul) System of Records and Strategic Information of the Environment was used as source of the data, through which the entire procedure for grant application and analysis is carried out. Interpolation maps were created using the Inverse Distance Weighting (IDW) method, which uses known values to estimate unknown values to better represent spatially the possible concentration of the analyzed parameters. Some parameters showed changes that varied according to the location of the wells, rural or urban, such as the concentration of nitrate in the water of six wells corresponding to levels above $10 \mathrm{mg} / \mathrm{L}$. In general, according to
\end{abstract}

* joaomiguelbega@gmail.com 
CONAMA Resolution $n^{\circ} 396 / 2008$, for the evaluated parameters, Campo Grande water is considered of good quality for recreational use and of relatively good quality for human consumption, as there are parameters in disagreement with the Consolidation Ordinance $\mathrm{n}^{\circ}$ $5 / 2017$.

Keyword: water resources, hydrogeology, urban pollution

\section{INTRODUÇÃO}

A exploração das águas subterrâneas no mundo assume grandes proporções devido a inúmeras vantagens, como a qualidade da água, os custos de explotação e o tratamento simplificado para consumo (UECHI et al., 2017). A água possui a capacidade de dissolver e incorporar substâncias no contato com minerais dos solos e das rochas, bem como características físicas de ordem estética sabor, salinidade, odor, condutividade elétrica e sólidos em suspensão (SANTOS, 2008). Além disso, quando possui boa qualidade, seu tratamento é dispensado para consumo humano. Todavia, contaminações de origem antrópica e natural podem ocorrer (PAULI et al., 2014).

O Instituto de Meio Ambiente de Mato Grosso do Sul (IMASUL), por meio do Manual de Outorga do Mato Grosso do Sul (MATO GROSSO DO SUL, 2015a), definiu os parâmetros a serem quantificados, cujos teores determinam a qualidade da água, a saber: temperatura da água, alcalinidade total, $\mathrm{pH}$, sólidos totais dissolvidos, turbidez, cor, dureza total, nitrato, nitrito, fluoreto, sulfato, sódio, cloreto, ferro total, condutividade elétrica, coliformes totais, coliformes termotolerantes e Escherichia coli (E. coli). Tais variáveis devem atender as concentrações estabelecidas pela Resolução do Conselho Nacional de Meio Ambiente (CONAMA) no 396 de 2008 e pela Portaria de Consolidação $\mathrm{n}^{\circ} 5$ do Ministério da Saúde de 28 de setembro de 2017, quando estabelecido valor máximo permitido (VMP).

Com o aumento da urbanização, industrialização e da população, a exploração de águas subterrâneas se dá sem planejamento, controle e sem considerar as atividades antrópicas e a vulnerabilidade natural dos aquíferos, colocando em risco a saúde humana e do meio ambiente (UECHI et al., 2017). De acordo com Luz et al. (2017), é crescente o número de surtos de infecção que tem como fonte o recurso hídrico subterrâneo, com traços de contaminantes e patógenos, entre bactérias, vírus e protozoários.

Conforme os fundamentos da Política Nacional de Recursos Hídricos (PNRH), a gestão de recursos hídricos deve sempre proporcionar o uso múltiplo das águas e de forma descentralizada com a participação do Poder Público, dos usuários e comunidades (BRASIL, 1997). De acordo com a Constituição do Estado do Mato Grosso do Sul, Art. 7, a água subterrânea é um bem do Estado (MATO GROSSO DO SUL, 1989).

No Estado do Mato Grosso do Sul, a Resolução $n^{\circ} 40$ de 03 de outubro de 2016, do Conselho Estadual de Recursos Hídricos (CERH), estabelece critérios de usos de recursos hídricos subterrâneos considerados insignificantes (não outorgáveis). Poços tubulares que não são considerados insignificantes devem ser outorgados de acordo com a Resolução da Secretaria de Estado de Meio Ambiente e Desenvolvimento Econômico (SEMADE) $\mathrm{n}^{\circ} 21$ de 27 de novembro de 2015, que estabelece as regras para a solicitação, análise e monitoramento da outorga de direito de uso de recursos hídricos no Estado de Mato Grosso do Sul (MATO GROSSO DO SUL, 2015a).

Contudo, em âmbito estadual, poços improdutivos, economicamente inviáveis, abandonados definitivamente ou não, cuja exploração cause alterações qualitativas na água subterrânea, não atendendo à 
Associação Brasileira de Normas Técnicas (ABNT) de projeto e construção de poços tubulares para captação de água subterrânea, respectivamente - Norma Brasileira (NBR) 12212 de 2017 e NBR 12244 de 2006 -, ou que apresentem a comprovação de contaminação do aquífero que inviabilize sua utilização, devem ser tamponados, de acordo com procedimento específico explícito na Resolução SEMADE $\mathrm{n}^{\mathrm{o}} 21$ de 2015 (MATO GROSSO DO SUL, 2015a).

Tal desativação deve ser feita somente para poços contaminados e com a devida comprovação do fato, após análise físico-química e microbiológica da água e descontaminação do poço (MATO GROSSO DO SUL, 2015a). Entretanto, esse tamponamento estava sendo realizado em virtude da presença de rede pública de abastecimento de água, para cumprimento do Art. $9^{\circ}$ do o Decreto municipal $n^{\circ} 12071$ de 27 de dezembro de 2012. Desta forma, justifica-se a importância da avaliação da qualidade da água subterrânea de Campo Grande - MS.

A utilização da água no município de Campo Grande - MS, por meio de poços tubulares, é um assunto que tem promovido discussões desde 2012, em decorrência do Decreto municipal $\mathrm{n}^{\circ} 12071$ de 27 de dezembro de 2012, que aprova e regula os serviços púbicos de abastecimento de água, coleta e tratamento de esgoto da área urbana supracitada. Neste Decreto é definido no Art. $9^{\circ}$ que não será autorizada a utilização de poços para abastecimento em locais onde há a rede pública de abastecimento de água e locais já alcançados pela mesma terão os poços tamponados. O parágrafo único, do mesmo Art., - incluído pelo Decreto $\mathrm{n}^{\circ}$ 12623 de 5 de maio de 2015 - exclui a proibição de utilização da água de poços para todos aqueles que possuem o devido licenciamento ou Certificado de Registro de Poço (CRP), documento que regulamentava o poço tubular, conforme Resolução da Secretaria de Estado de Meio Ambiente, do Planejamento, da Ciência e Tecnologia (SEMAC) nº 008 de 6 de julho de 2009, a qual dispõe sobre o licenciamento ambiental de poços tubulares para captação de água no Mato Grosso do Sul.

No entanto, a Resolução SEMAC $n^{\circ}$ 008 de 2009 foi revogada pela Resolução SEMADE $\mathrm{n}^{\circ} 21$ de 27 de novembro de 2015, que estabelece as normas e procedimentos para a outorga de direito de uso dos recursos hídricos de Mato Grosso do Sul, já prevista como condicionante no $\mathrm{CRP}$, determinando que o usuário deveria solicitar a outorga de direito de uso de água assim que as normas fossem estabelecidas.

Em julho de 2016 o Tribunal de Justiça do Estado do Mato Grosso do Sul declarou a inconstitucionalidade formal do artigo $9^{\circ}$, caput e incisos I e II, do Anexo Único, do Decreto Municipal no 12071 de 2012. Além disso, revogou integralmente o Decreto Municipal no 12.636 de 25 de maio de 2015, por afrontarem aos artigos $7^{\circ}$, inciso II e artigo 234, inciso I, da Constituição do Estado do Mato Grosso do Sul. Visto que a legislação municipal, ao vedar a utilização dos poços e determinar seu tamponamento, contraria a norma estadual que prevê a possibilidade de concessão de outorga de usos de recursos hídricos.

Ademais, por não ser competência do município a gestão da água subterrânea, posicionando-a como um bem natural gerido pelo Estado, nota-se que ela se torna, por conseguinte, objeto de disputa no campo econômico e jurídico e afeta a população e os usuários de forma direta, pois a proibição da utilização desse recurso acarreta no encarecimento dos serviços e produtos oferecidos à sociedade.

Pela relevância social em que esse campo de disputas se coloca, a pesquisa objetivou avaliar, discutir e disponibilizar dados para a sociedade sobre a qualidade das águas subterrâneas ( $\mathrm{pH}$, turbidez, nitrito, nitrato, sulfato e coliformes termotolerantes) no município de Campo Grande - MS, a fim de subsidiar futuras decisões sobre operação e manutenção dos poços utilizados pelo município. 


\section{MATERIAL E MÉTODOS}

\section{Caracterização da área de estudo}

Segundo dados do Instituto Brasileiro de Geografia e Estatística (IBGE, 2015), a área do município de Campo Grande é de $8.092,9 \mathrm{~km}^{2}$, tendo a área urbana 35.903,5 ha. O Estado de Mato Grosso do Sul está localizado na região Centro-Oeste brasileira e, conforme a Agência Municipal de Meio Ambiente e Planejamento Urbano, a cidade em estudo se encontra inserida na porção central do estado, com a sede municipal entre as imediações do divisor de águas das bacias do Paraná e Paraguai, estabelecido pelas coordenadas geográficas $20^{\circ} 28^{\prime} 13^{\prime \prime}$ latitude Sul e 54'37'25" longitude Oeste, apresentando altimetria entre 500 e 675 m (PLANURB, 2017).

De acordo com o Plano Estadual de Recursos Hídricos (PERH) do Mato Grosso do Sul de 2010, a área total do município de Campo Grande inserida na Unidade de Planejamento e Gerenciamento (UPG) Pardo é de $93,28 \%$ ou $7.552,362 \mathrm{~km}^{2}$. Tal UPG encontra-se localizada a Centro-Leste do estado, na região hidrográfica do Paraná.
Já na bacia hidrográfica do Paraguai, o município apresenta $6,72 \%$ ou $543,69 \mathrm{~km}^{2}$ do seu território localizado na UPG Miranda.

Na cidade de Campo Grande foram outorgados 146 poços tubulares até outubro de 2018, com a água destinada a diversas finalidades de uso: abastecimento público, consumo humano, dessedentação de animais, indústria, mineração, irrigação e outras finalidades de uso. É importante frisar que, de 146 pontos de captações subterrâneas outorgadas, há 74 poços destinados a outras finalidades de uso, representando $50,6 \%$ do total de pontos em estudo.

A Figura 1 apresenta a área urbana de Campo Grande, de acordo com Plano Diretor de Desenvolvimento Urbano Ambiental de Campo Grande (PDDUA) de 27 de outubro de 2017. Considerando que a maior ocorrência dos poços outorgados do município está nessa região, é necessário maior enfoque nesse perímetro. Além disso, a Figura 1 mostra os aquíferos aflorantes na área urbana do município. 


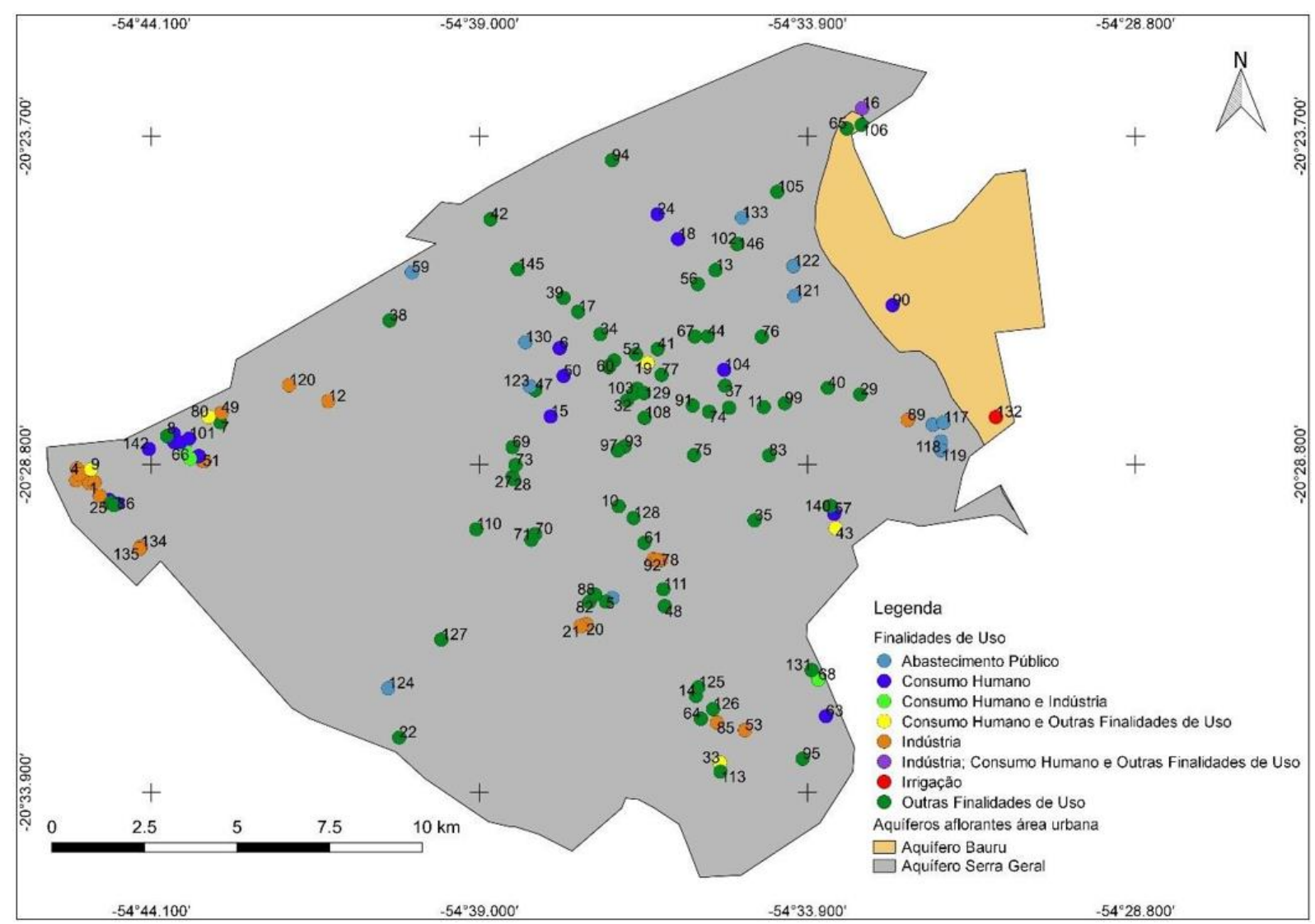

Figura 1 - Delimitação do perímetro urbano do município de Campo Grande - MS, poços outorgados, finalidades de usos e aquíferos aflorantes.

No perímetro urbano não há captações subterrâneas outorgadas destinadas às finalidades de mineração e dessedentação de animais, somente para as finalidades de abastecimento público, consumo humano, indústria, irrigação e outras finalidades de uso.

Quanto à geologia, a Figura 2 mostra as unidades hidrogeológicas aflorantes no estado de Mato Grosso do Sul. De acordo com o PERH/MS, a base de dados foi confeccionada a partir do mapa geológico da Companhia de Pesquisa de Recursos Minerais (CPRM, 2006), com escala de 1:1.000.000.

O Sistema Aquífero Guarani (SAG) é classificado como poroso. Em Campo Grande, ele apresenta uma pequena área de afloramento, porém é bastante utilizado para o abastecimento público a partir de poços tubulares profundos, que captam água de dois aquíferos. O Sistema Aquífero
Serra Geral (SASG), por sua vez, aflorante no município em análise, é composto essencialmente por basaltos, caracterizado como aquífero fraturado. O Sistema Aquífero Bauru (SAB), aflorante no município de Campo Grande, é constituído por rochas sedimentares do Grupo Caiuá Indiviso, compostas de arenito quartzoso a subarcoseano, fino a médio (CPRM, 2006). A água deste aquífero ocorre em meio poroso. $\mathrm{O}$ aquífero Bauru em sua área geral é formado pelos Grupos Bauru e Caiuá (CPRM, 2006). Esta divisão considera as Formações Vale do Rio do Peixe e Marília inseridas no Grupo Bauru, com as Formações Caiuá e Santo Anastácio pertencentes ao Grupo Caiuá. Ainda que haja diferenças entre tais formações, o PERH/MS de 2010 considera, em termos hidrogeológicos, todo o pacote da Bacia Bauru como SAB (UECHI et al., 2017). 


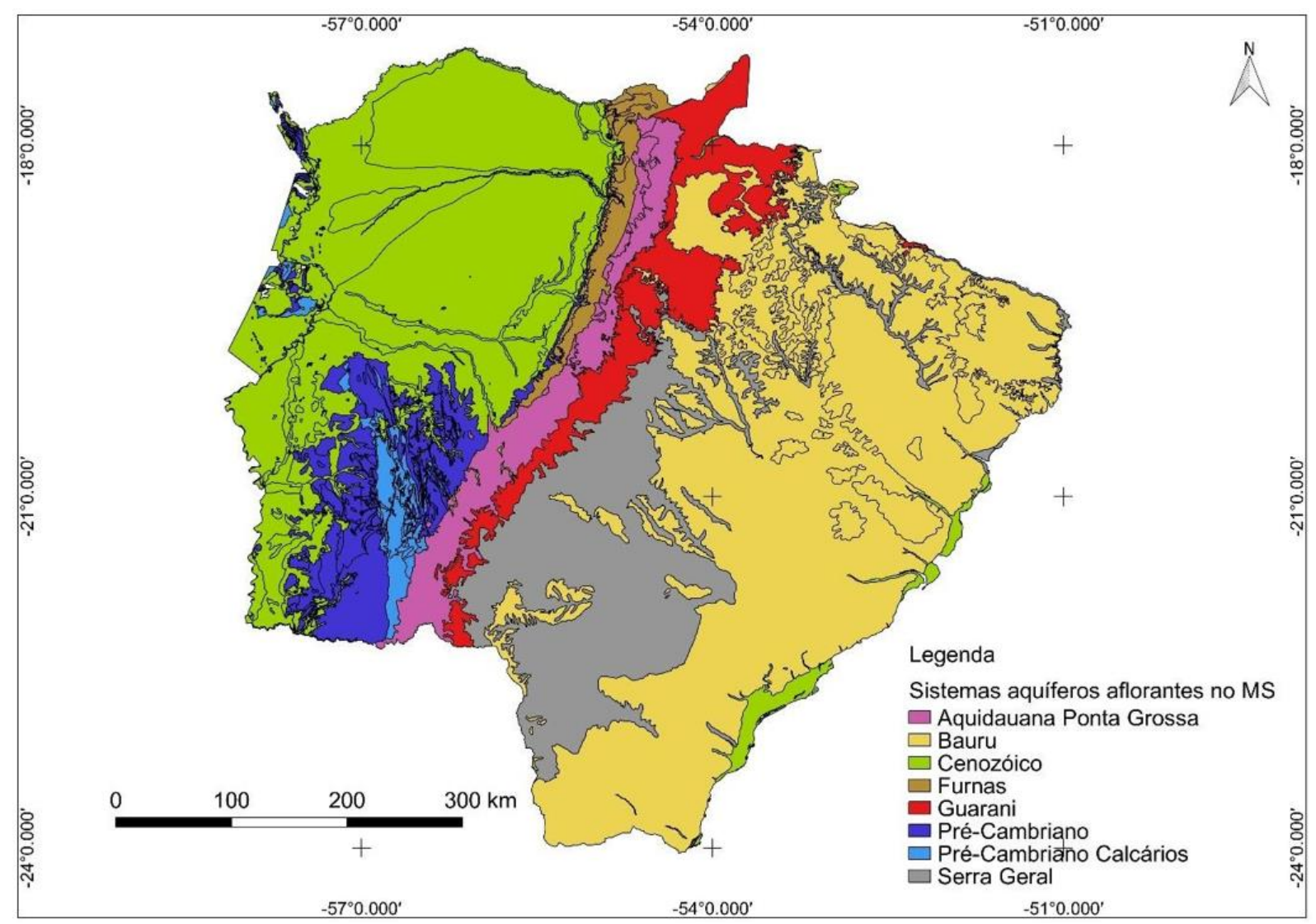

Figura 2 - Sistemas aquíferos livres no Estado do Mato Grosso do Sul (CPRM, 2006).

Em relação à litologia da área em estudo (Figura 3), encontram-se rochas sedimentares da Formação Pirambóia na base, compostas essencialmente por arenito fino, de coloração vermelha, grãos subangulares à semi-arredondados, com intercalações silto-argilosas (TAHAL, 1998).

Acima do Arenito Pirambóia ocorre o Arenito Botucatu, que compreende arenitos finos a médios, de cor avermelhada, friáveis, com grãos arredondados e alta esfericidade, possuindo estratificações cruzadas originadas da formação de dunas em ambiente desértico, onde encontra-se o principal reservatório do aquífero Guarani (MMA, 2008).

Sobreposto ao Arenito Botucatu ocorrem rochas vulcânicas do tipo basálticas pertencentes ao Grupo São Bento, Formação Serra Geral, que, por sua vez, é composta por uma sequência de derrames basálticos, além de arenitos intertrapeanos, com idade jurássicacretácica (CORDANI \& VANDOROS,
1967). Litologicamente, esses basaltos possuem aspecto maciços afaníticos ou finamente faneríticos, cor de cinza escuro a preto, apresentam estruturas vesículoamigdaloidal, preenchidas por calcitas, quartzo, clorita e zeolitas, principalmente no topo e base do derrame basáltico (TAHAL, 1998).

De acordo com Campos (2004), o Grupo Bauru é formado por arenitos finos, mal selecionados na base e argilosos a calcíferos no topo. Já o Grupo Caiuá é constituído de arenitos finos a muito finos, quartzosos bem selecionados, de coloração marrom avermelhada a arroxada, que apresentam alta maturidade textural e mineralógica, com grãos de brilho fosco e películas de óxido de ferro, ocorrendo sobre os basaltos da formação Serra Geral (BATEZELLI, 2010).

O Grupo Bauru é representado pelas Formações Marília e Vale do Rio do Peixe e o Grupo Caiuá é constituído pela formação Santo Anastácio (CPRM, 2006), além de rochas consideradas do Grupo 
Caiuá indiviso (FERNANDES \& BRANCO, 2015; CPRM, 2006).

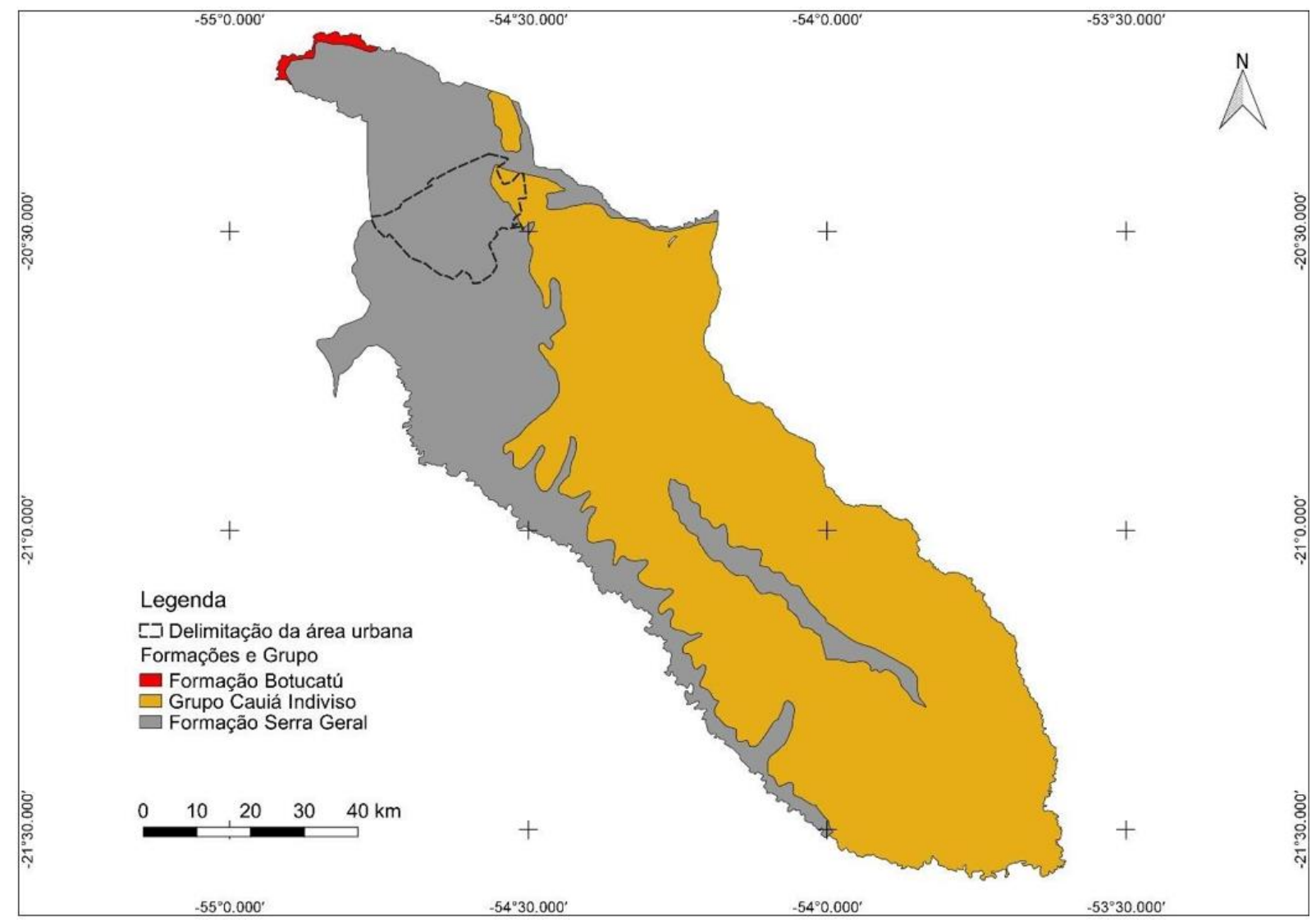

Figura 3 - Formações e Grupo geológicos aflorantes no município de Campo Grande - MS (CPRM, 2006).

\section{Análises físico-químicas e microbiológicas}

Para a consecução do estudo foram utilizados dados secundários de análises físico-químicas e microbiológicas inseridos no Sistema IMASUL de Registros e Informações Estratégicas do Meio Ambiente (SIRIEMA), referentes aos 149 poços outorgados no município de Campo Grande, como parte dos documentos necessários à solicitação de outorga das águas subterrâneas no Mato Grosso do Sul, realizadas por laboratórios credenciados no IMASUL e coletadas pelos responsáveis técnicos pelo processo ou laboratório, ou pelo usuário solicitante. Tais análises de água foram feitas conforme o Standard Methods for the Examination of Water and Wastewater (SMEWW), porém com edições e anos de publicação divergentes (APHA, 2005; APHA, 2012). Os seguintes parâmetros foram estudados na presente pesquisa: $\mathrm{pH}$, turbidez, nitrato, nitrito, sulfato e coliformes termotolerantes.

Em junho de 2015 foi publicada a Resolução SEMADE $\mathrm{n}^{\circ}$ 11, a qual estabelece a obrigatoriedade de credenciamento dos laboratórios que prestam serviços ambientais junto ao IMASUL, além de estabelecer critérios, normas e procedimentos técnicos para acreditação no prazo máximo de um ano a partir de sua publicação (MATO GROSSO DO SUL, 2015b).

Todas as coletas e entregas das amostras de água aos laboratórios foram realizadas entre 29 de outubro de 2015 e 24 de setembro de 2018, destinadas a avaliar a qualidade da água subterrânea do respectivo poço tubular.

É importante salientar que os poços de 1 a 146 só possuem um laudo de análise de água, com exceção daqueles que, em anexo ao SIRIEMA, não apresentaram 
todos os parâmetros exigidos pelo manual de outorga do Mato Grosso do Sul e/ou precisaram realizar a correção da água para enquadrar parâmetros que possuíam uma concentração acima do VMP pelas legislações pertinentes, conforme o uso preponderante, após ofício de pendências. $\mathrm{E}$, dentre os poços, alguns apresentaram a análise da água tratada, além de análises complementares.

\section{Mapas de concentrações dos parâmetros}

Para a criação dos mapas de concentrações dos parâmetros avaliados foi

$$
u(x)=\sum_{i=0}^{N} \frac{w_{i}(x) u_{i}}{\sum_{j=0}^{N} w_{j}(x)}
$$

Ainda, pela Equação 2, tem-se:

$$
w_{i}(x)=\frac{1}{d\left(x, x_{1}\right)^{p}}
$$

$p$ : potência utilizada.

Os mapas de interpolação IDW foram confeccionados no programa de geoprocessamento Qgis Desktop, versão 2.18.0, por meio do Complemento de Interpolação, disponível no menu Raster, após instalação.

A interpolação foi realizada por meio das concentrações do parâmetro em análise de cada ponto. Além disso, foi necessário

\section{RESULTADOS E DISCUSSÃO}

\section{Parâmetros físico-químicos e microbiológico}

\section{pH}

O pH apresenta alteração em seu valor, conforme ocorre a mudança na temperatura da água. De acordo com a Portaria de Consolidação $n^{\circ} 5 / 2017$, é recomendado para consumo humano que a água apresente valores de pH entre 6 e 9. Nos poços analisados, $20,5 \%$ resultaram em um valor abaixo do recomendado pela Portaria, o que pode ser prejudicial à saúde humana, devido ao fato da água possuir tendências ácidas. Entretanto, tal inserir as coordenadas do local. Após o recorte do arquivo raster gerado, em propriedades da camada, na aba Estilo, o tipo de renderização escolhido foi a Banda Simples Falsa-Cor, sendo definidas as concentrações de acordo com o VMP pela Portaria de Consolidação $n^{\circ} 5$ e Resolução CONAMA n 396 de 2008 ou conforme intervalos mínimos e máximos do contaminante em análise.

característica pode ser relativa ao aquífero explorado, pois 30 poços fazem captação do (SASG) e, dentre estes, 7 explotam água do Sistema (SAB).

Conforme a Figura 4, confeccionada a partir da interpolação IDW somente com dados da área urbana do município em análise, os poços do SAB apresentaram tendências de $\mathrm{pH}$ entre 5 e 6 . Já para o SASG, em alguns poços próximos aos córregos do município, foram verificados pH ente 4 e 5 , o que, por sua vez, pode estar relacionado com a água superficial, em detrimento do aumento da temperatura. 


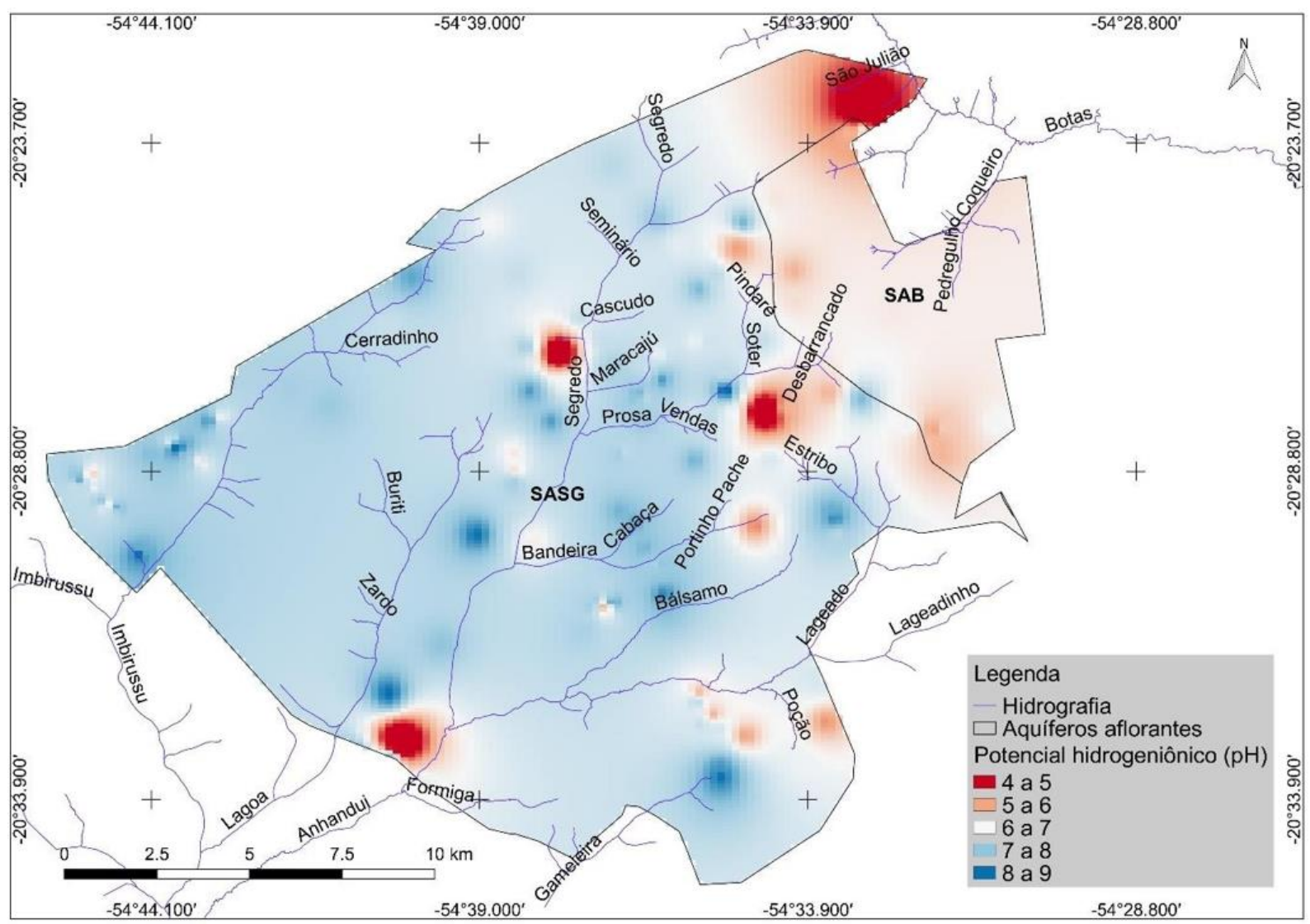

Figura 4 - Mapa de interpolação IDW referente ao pH da água dos poços tubulares outorgados na área urbana de Campo Grande - MS.

Corcóvia e Celligoi (2012) avaliaram a qualidade da água de dois poços tubulares penetrantes do SAG e 25 poços do SASG, situados na cidade de Ibiporã, no Estado do Paraná, para fins de abastecimento público. Em relação a esse parâmetro químico, os autores encontraram valores que estiveram entre 6,0 e 8,5, sendo aferidos valores elevados em poços do SASG. No presente trabalho, os valores de $\mathrm{pH}$ preocupantes se encontram abaixo do limite inferior estabelecido pela Portaria.

\section{Turbidez}

A turbidez foi quantificada em 144 poços outorgados. Somente as fontes de captação $\mathrm{n}^{\circ} 42$ e 58 não apresentaram a análise desse parâmetro físico, responsável por representar o grau de dificuldade da passagem da luz no meio fluido.

A Portaria de Consolidação $\mathrm{n}^{\circ} 5$ de 2017 determina que a unidade de turbidez (uT) máxima é 5. As captações P9, P33 e
P71 apresentaram 5,6; 420 e 6,4 uT, respectivamente. Os poços $\mathrm{P} 9$ e P33 são utilizados para consumo humano e outras finalidades de uso. O poço P71 obteve a outorga da água para outras finalidades de uso.

Sem a devida limpeza da fonte de captação, a água dos poços P9 e P33 não devem ser utilizadas para consumo, principalmente o primeiro, pois apresenta uma água de cor turva. Apesar de não ser prejudicial à saúde humana, confere à água um aspecto menos límpido.

A partir do mapa de interpolação pelo método IDW (Figura 5) é possível verificar a concentração de poços com turbidez de 5 a 420 uT no extremo sul-sudeste da área urbana do município analisado. A região em vermelho concentra valores de turbidez acima do VMP para consumo humano, de acordo com Portaria de Consolidação $\mathrm{n}^{\circ} 5$ de 2017. 


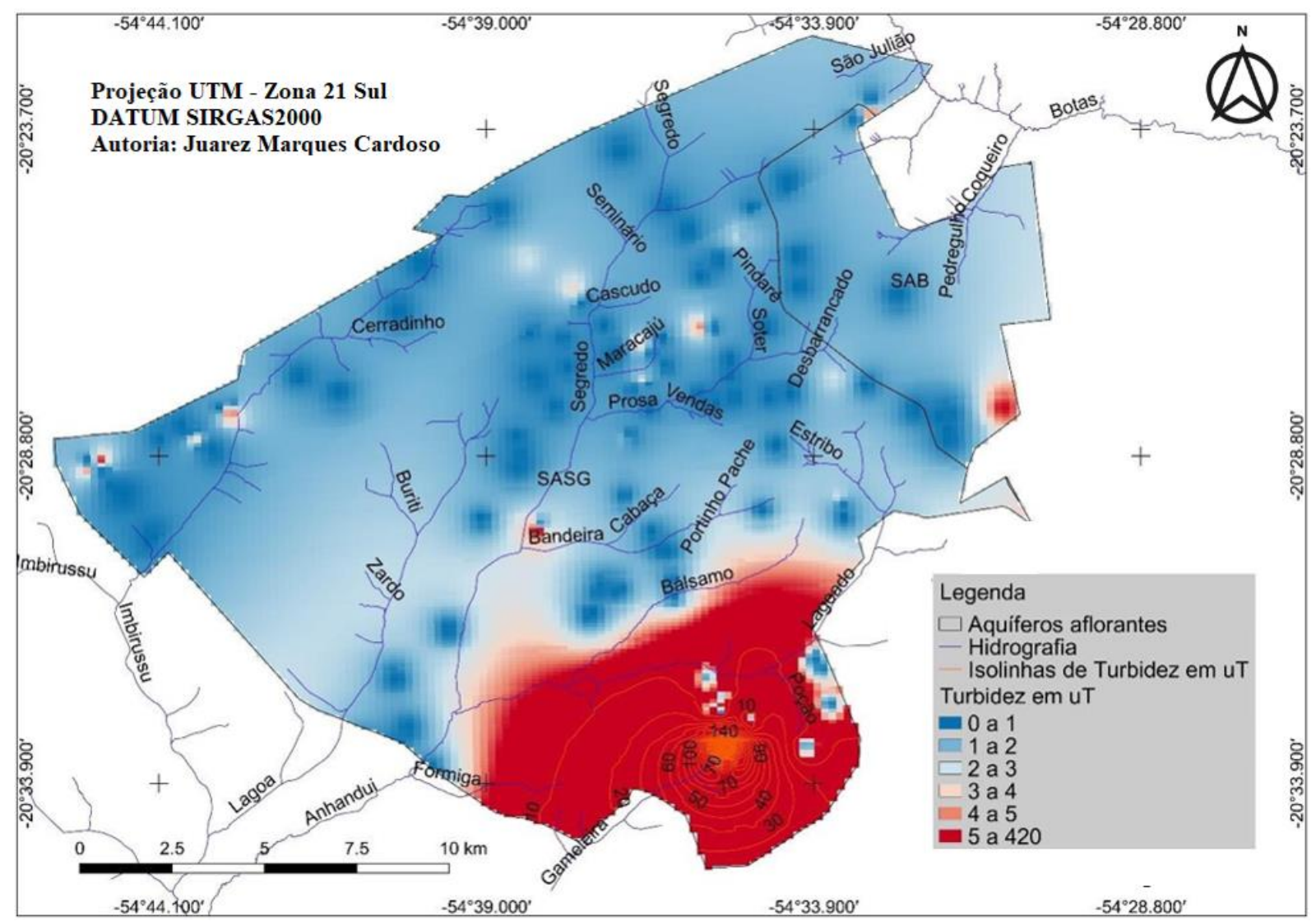

Figura 5 - Mapa de turbidez em uT conforme VMP pela legislação da água dos poços outorgados na área urbana de Campo Grande - MS.

\section{Nitrato}

Em termos de dados, apenas $2,7 \%$ dos pontos em análise não apresentaram a quantificação do nitrato. Dentre os 146 poços analisados, os maiores teores apresentados foram verificados no P35 (230,80 mg/L) e no P125 (140,72 mg/L). Ambos destinam a água para outras finalidades de uso, com fins menos restritivos.

O P90 apresentou uma concentração de $67,89 \mathrm{mg} / \mathrm{L}$ de nitrato, sendo sua água destinada ao consumo humano. Ele localiza-se no perímetro urbano, contudo, bem próximo aos limites em que se inicia o perímetro rural, inferindo uma possível contaminação por fertilizantes nitrogenados e/ou fossas sépticas. Esta concentração apresenta-se acima do VMP pela Portaria de Consolidação $n^{\circ} 5$ de 2017, correspondente a $10 \mathrm{mg} / \mathrm{L}$.

A captação subterrânea $\mathrm{n}^{\circ} 104$ apresentou uma concentração de 39,94 $\mathrm{mg} / \mathrm{L}$ e é utilizada para a finalidade de consumo humano, localizada em área urbana. Ainda, o P122, utilizado para abastecimento público, apresentou na análise da água bruta o teor de 11,03 mg/L.

Varnier et al. (2010) realizaram um monitoramento em amostras de água do $\mathrm{SAB}$ em poços tubulares situados em área urbana do município de Marília, localizado no Estado de São Paulo. Os autores obtiveram as maiores concentrações de nitrato em áreas com ocupação urbana mais antiga e em poços com profundidades de até $150 \mathrm{~m}$. O teor máximo encontrado foi de $16,9 \mathrm{mg} / \mathrm{L}$, inferior ao levantado no presente trabalho, igual a $230,80 \mathrm{mg} / \mathrm{L}$. Eles verificaram que a contaminação relacionava-se aos sistemas de esgotamento sanitário, ocorrendo predominantemente no Aquífero Marília.

Os poços P18 (9 mg/L), P46 (9,9 $\mathrm{mg} / \mathrm{L})$, P52 (9,2 mg/L), P94 (10 mg/L) e P124 (9,28 mg/L) requerem cautela, uma vez que apresentaram um teor próximo ou igual ao VMP pela Portaria de Consolidação $\mathrm{n}^{\circ}$ 5. Dentre os 5 poços discutidos neste parágrafo, somente o P46 
está localizado em perímetro rural. A concentração deste último pode ser justificada pelo uso de fertilizantes e/ou de esterco animal, que conduz ao aporte de nitrogênio ao subsolo.

Para melhor representação da quantificação de nitrato na área urbana do município de Campo Grande, foi criado o mapa de interpolação pelo método IDW (Figura 6), com o intuito de identificar os pontos que apresentaram concentrações acima do VMP para consumo humano. Além disso, foram criadas as linhas de contorno, por meio do arquivo raster, a cada $5 \mathrm{mg} / \mathrm{L}$, para identificação dos maiores teores do contaminante.

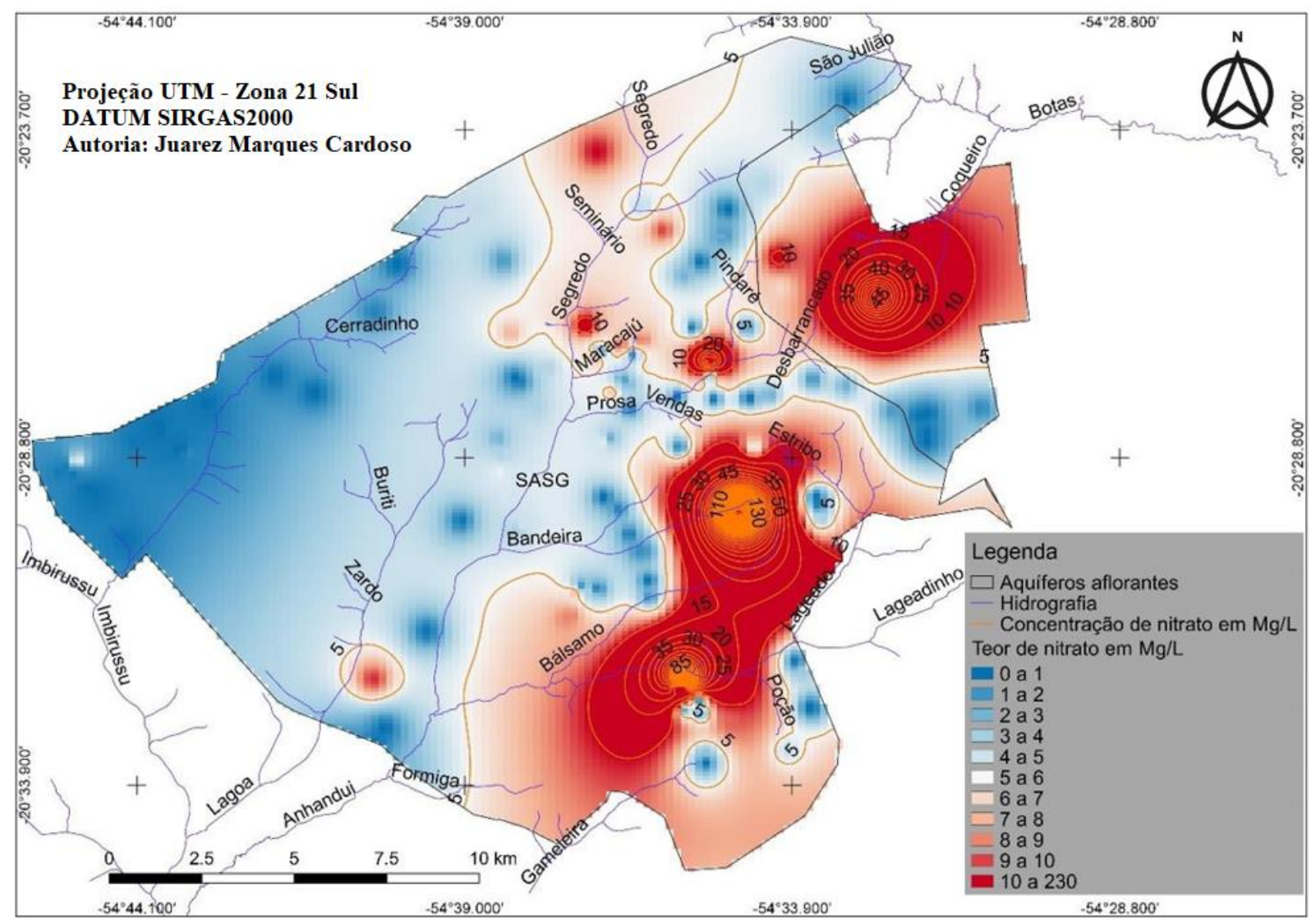

Figura 6 - Mapa da concentração de nitrato dos poços outorgados na área urbana do município de Campo Grande - MS, conforme VMP.

No extremo nordeste do mapa é apresentada a tendência para concentrações de até $60 \mathrm{mg} / \mathrm{L}$, explicada pela proximidade com o perímetro rural.

\section{Nitrito}

Todos os poços apresentaram um teor de nitrito abaixo do VMP pela Portaria de Consolidação $\mathrm{n}^{\circ} 5$, igual a $1 \mathrm{mg} / \mathrm{L}$, adotado para proteger a população da metemoglobina. Desta forma, considerando o parâmetro nitrito, a água subterrânea de Campo Grande é de excelente qualidade para a finalidade de consumo humano e para as demais finalidades previstas na Resolução CONAMA $\mathrm{n}^{\circ} 396$ menos restritivas.

A Figura 7 refere-se ao mapa de interpolação pelo método IDW para o teor de nitrito em $\mathrm{mg} / \mathrm{L}$, sendo possível verificar que não há concentrações acima do VMP pela Portaria de Consolidação no 5 de 2017. 


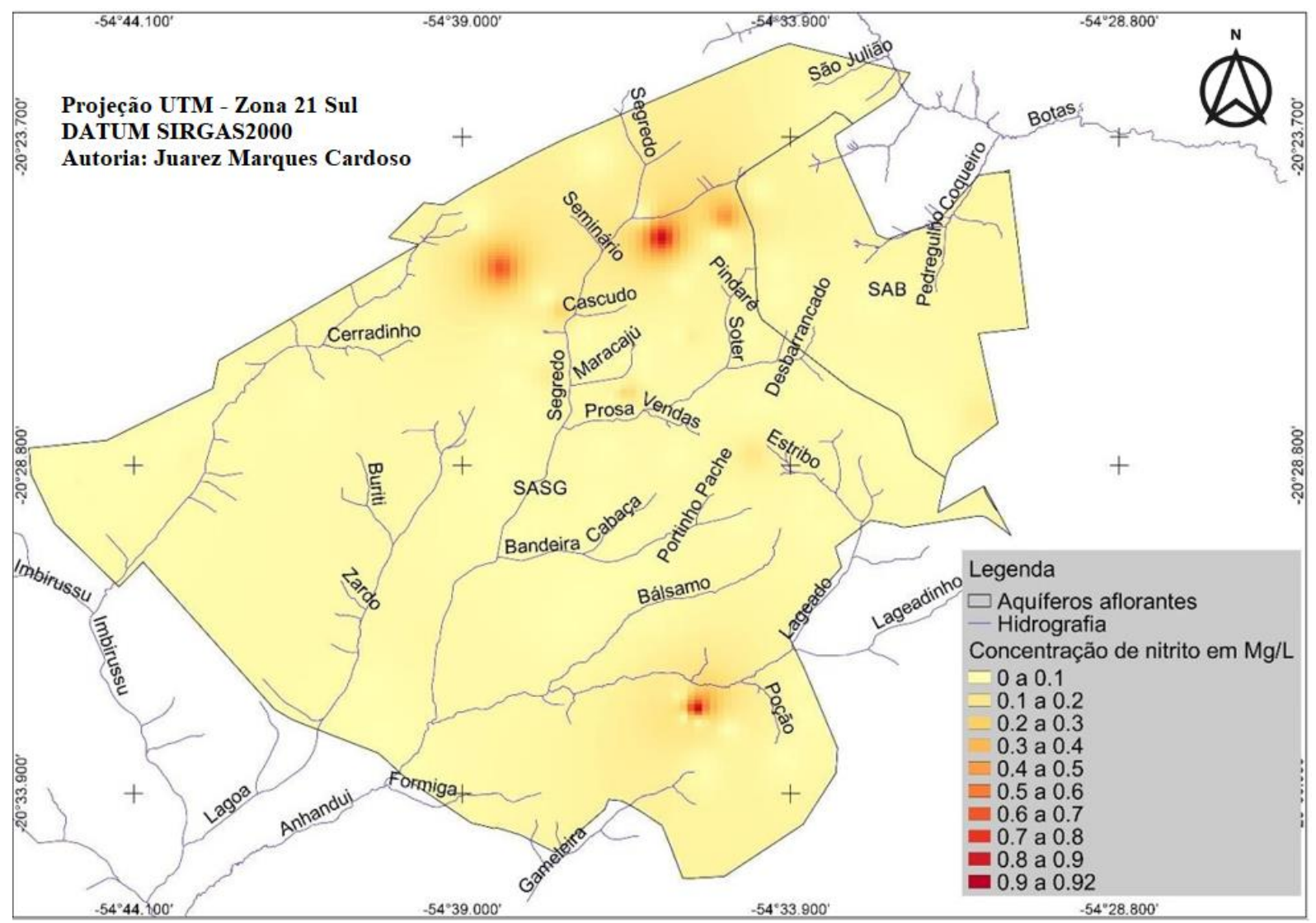

Figura 7 - Mapa de interpolação pelo método IDW da concentração do parâmetro nitrito presente na água dos poços outorgados na área urbana de Campo Grande - MS.

\section{Sulfato}

Não foram informadas as concentrações desse parâmetro para as captações subterrâneas P3, P4, P5, P11, P58, P61, P83 e P94. Assim, 138 poços apresentaram a quantificação de sulfato, com alguns não determinados (ND). Todos os poços que apresentaram valores desse parâmetro estavam em conformidade com as legislações que determinam os VMP para consumo humano $(250 \mathrm{mg} / \mathrm{L})$. Por fim, pode-se garantir que a água subterrânea dos poços outorgados no município de Campo Grande apresenta boa qualidade para consumo e para usos menos restritivos em relação ao sulfato.

Pela Figura 8, pode-se verificar que as maiores concentrações de sulfato - até 181 mg/L - localizam-se a sul da área urbana, presentes apenas no SASG. 


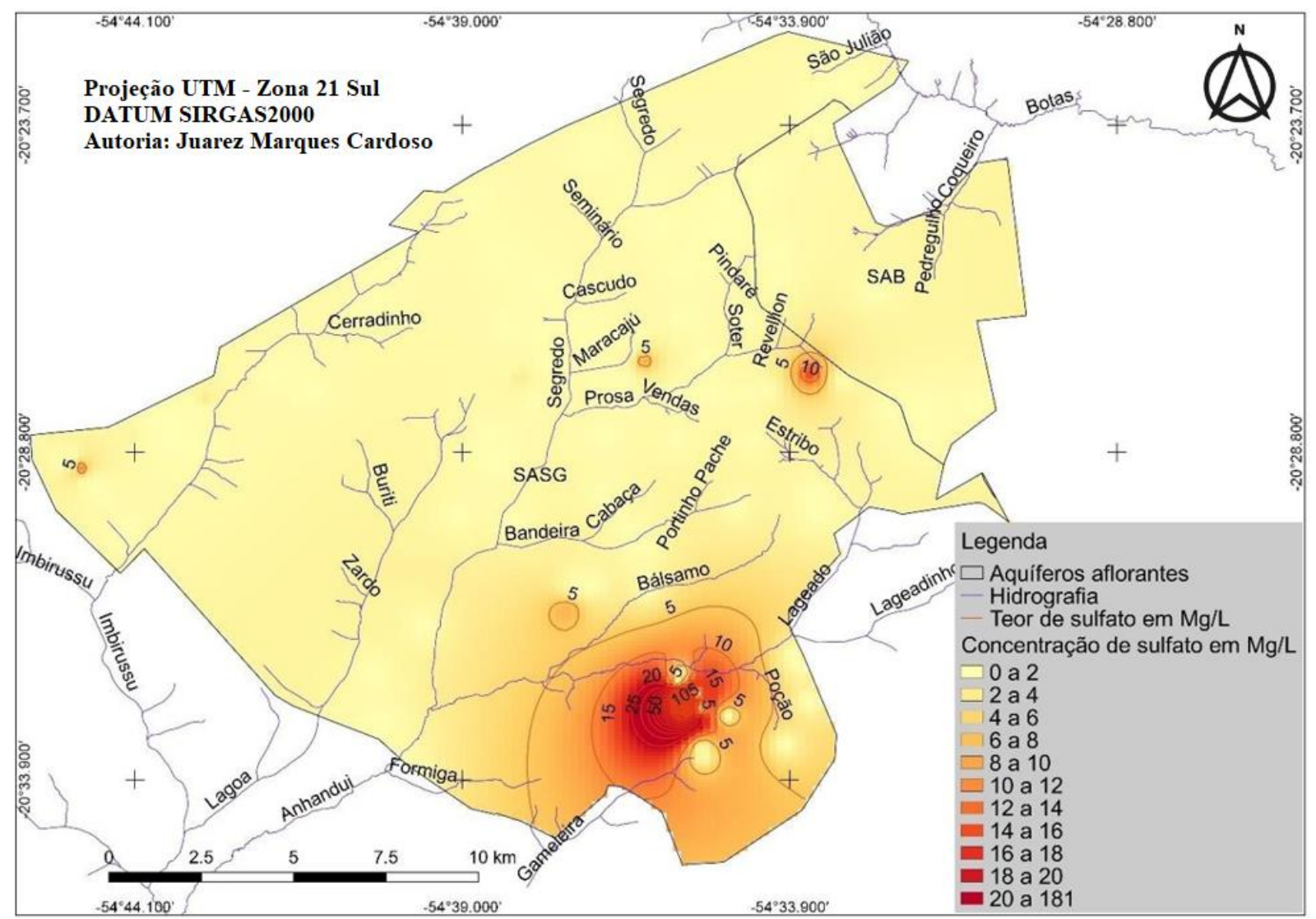

Figura 8 - Mapa de interpolação pelo método IDW conforme concentração de sulfato presente na água dos poços tubulares outorgados em Campo Grande - MS.

\section{Coliformes termotolerantes}

As análises dos coliformes termotolerantes foram apresentadas em quase todos os processos de solicitação de outorga como Escherichia coli (E. coli), tendo em vista que a maior parte do grupo dos coliformes termotolerantes é representada pelas bactérias do tipo E. coli. Desta maneira, somente algumas análises apresentaram separadamente os dois parâmetros.

Dentre os poços em estudo, 10,2\% não apresentaram o parâmetro coliformes termotolerantes, ou seja, 15 captações, mas apresentaram o parâmetro E.coli separadamente, com exceção do P11, que não informou nenhuma quantificação microbiológica.

$\mathrm{O}$ primeiro laudo vinculado ao poço P60 resultou em um valor de 461 NMP/100 $\mathrm{mL}$ de coliformes termotolerantes. Após desinfecção do poço, foi apresentada uma segunda análise, mostrando ausência para os coliformes termotolerantes.

Não exclusivamente de origem fecal, a presença dos coliformes termotolerantes em alta concentração pode sugerir vazamentos na rede de esgoto e fossas sépticas da área urbana locacional. Esta situação pode ocasionar agravos à saúde humana.

Malheiros et al. (2009) avaliaram a qualidade bacteriológica de águas subterrâneas da região Oeste do Estado de Santa Catarina. Do total de 212 amostras analisadas, $161 \quad(75,94 \%)$ estavam impróprias para o consumo humano conforme a Portaria 2914/2011 do Ministério da Saúde. Os autores fizeram também um levantamento de dados por meio de um questionário para verificar o grau de satisfação dos consumidores. Apesar dos altos índices de contaminação bacteriológica nas amostras avaliadas, a maioria dos consumidores julgou a água de boa qualidade.

Luz et al. (2017) encontraram coliformes termotolerantes em $66,6 \%$ das 27 amostras avaliadas no município de Ivoti (RS), na porção aflorante do Aquífero 
Guarani. Ademais, 25,9\% das amostras foram positivas para E. coli. Aproximadamente 1/4 dos poços testados não atenderam a portaria vigente. No município de Campo Grande, para os poços

\section{CONCLUSÕES}

A partir dos resultados obtidos com dados em análise do presente estudo, constatou-se que há poços tubulares outorgados na cidade de Campo Grande que deixaram de apresentar determinados parâmetros físico-químicos e microbiológicos, como a concentração de coliformes termotolerantes. Este parâmetro requer a investigação da vigilância sanitário-epidemiológica em saúde coletiva, uma vez que elevadas concentrações são sugestivas de perigos à saúde humana.

Há poços em que parte dos parâmetros apresentados estão em desacordo com os VMP pelas legislações pertinentes. Por isso, propõe-se que devam ser perfurados poços destinados ao monitoramento da água subterrânea na área urbana do município de Campo Grande,

\section{AGRADECIMENTOS}

O presente trabalho foi realizado com apoio da Coordenação de Aperfeiçoamento de Pessoal de Nível Superior - Brasil (CAPES) - Código de Financiamento 001. Os autores agradecem ao Programa de Mestrado Profissional em Rede Nacional em Gestão e Regulação de Recursos Hídricos -

\section{REFERÊNCIAS BIBLIOGRÁFICAS}

AMERICAN PUBLIC HEALTH ASSOCIATION - APHA. Standard methods for the examination of water and wastewater. USA, editor: APHA, 2005.

AMERICAN PUBLIC HEALTH ASSOCIATION - APHA. Standard methods for the examination of water and wastewater. USA, editor: APHA, 2012. quantificados nesta pesquisa, apenas o P60 resultou em uma concentração acima da permitida na água bruta, fato corrigido após desinfecção do poço.

com análises mensais, de acordo com os períodos chuvosos e de seca, principalmente para o nitrato, com a finalidade de determinar as possíveis fontes contaminantes, podendo ser derivadas de vazamentos na rede de esgoto e/ou pela contribuição da água dos afluentes do Rio Anhanduí aos aquíferos SAB e SASG.

É preciso maior atenção para os poços próximos aos córregos, pois alguns apresentaram uma concentração elevada de nitrato. Assim, verifica-se a necessidade de laje de proteção em todas as fontes de captação subterrânea. Além disso, deve-se evitar perfurações próximas aos córregos, para evitar a contaminação da água, causada pela interação entre a água subterrânea e superficial e alterações nas vazões naturais desses corpos d'água.

ProfÁgua, Projeto CAPES/ANA AUXPE $\mathrm{N}^{\circ} .2717 / 2015$, pelo apoio técnico científico aportado até o momento e um agradecimento também ao Conselho Nacional de Desenvolvimento Científico e Tecnológico - CNPq.

BATEZELLI, A. Arcabouço tectonoestratigráfico e evolução das Bacias Caiuá e Bauru no sudeste brasileiro. Revista Brasileira de Geociência v. 40, n. 2, p. 265-285, 2010.

BRASIL. Decreto $\mathrm{n}^{0} \mathbf{7 9 . 3 6 7}$ de 9 de março de 1977. Dispõe sobre normas e o padrão de potabilidade de água e dá outras providências. Brasília, DF, 1977. 
Disponível

em: http://www.planalto.gov.br/ccivil_03/decre to/1970-1979/D79367.htm. Acesso em: 10 jan. 2019.

CAMPOS, H. C. N. S. Águas subterrâneas na Bacia do Paraná. Geosul, v. 19, n. 37, p. 47-65, 2004.

COMPANHIA DE PESQUISA DE RECURSOS MINERAIS - CPRM. Mapa geológico do Estado de Mato Grosso do Sul. Escala 1:1.000.000. Serviço Geológico do Brasil. Secretaria de Geologia, Mineração e Transformação Mineral. Campo Grande, MS, 2006.

CORCÓVIA, J. A.; CELliGOI, A. Avaliação preliminar da qualidade da água subterrânea no município de Ibiporã - PR. Revista de Estudos Ambientais, v. 14, n. 2, p. 39-48, 2012.

CORDANI, U. G.; VANDOROS, P. Basaltics rocks of the Paraná Basin: problems in brazilian gondwana geology. Boletim Paranaense de Geografia, v. 21, n. 22, p. 207-231, 1967.

FERNANDES, L. A.; BRANCO, H. C. Calcretes neocretácicos da Formação Marília, Bacia Bauru. In: DIAS-BRITO, D.; TIBANA, P. Calcários do Cretáceo do Brasil: um atlas. Rio Claro: Unesp-IGCEUNES-Petro, p. 481-496, 2015.

INSTITUTO BRASILEIRO DE GEOGRAFIA E ESTATÍSTICA - IBGE. Informações

completas do Instituto Brasileiro de Geografia e Estatística. Rio de Janeiro, 2015.

LU, G. Y.; WONG, D. W. An adaptive inverse-distance weighting spatial interpolation technique. Computers and Geosciences, v. 34, p. 1044-1055, 2008.

LUZ, R. B. L.; STAGGEMEIER, R.; FRATTA, L. X. S; LONGO, L.; SCHUTZ, R.;
SOLIMAN, M.C.; KLUGE, M.; FABRES, R. B.; SCHENKEL, G. C.; BRUNI, F. P.; FLECK, J. D.; PICOLI, S. U.; SPILKI F. R. Contaminação viral e bacteriana em águas subterrâneas na porção aflorante do Aquífero Guaraní, município de Ivoti, RS. Ambiente \& Água, v. 12, n. 5, p. 871-880, 2017.

MALHEIROS, P. S.; SCHAFER, D. F.; HERBERT, I. M.; CAPUANI, S. M.; SILVA, E. M.; SARDIGLIA, C. U.; SCAPIN, D.; ROSSI, E. M.; BRANDELLI, A. Contaminação bacteriológica de águas subterrâneas da região Oeste de Santa Catarina, Brasil. Revista do Instituto Adolf Lutz, v. 68, n. 2, p. 305-308, 2009.

MATO GROSSO DO SUL. Constituição [1989]. Constituição do Estadual de Mato Grosso do Sul. Campo Grande, MS, 1989.

MATO GROSSO DO SUL. Resolução SEMADE $\mathbf{N}^{\circ} 21$ de 27 de novembro de 2015. Estabelece normas e procedimentos para a Outorga de Uso de Recursos Hídricos, e dá outras providências. Campo Grande, MS, 2015a.

MATO GROSSO DO SUL. Resolução SEMADE No 11 de 1 de junho de 2015. Dispõe sobre a obrigatoriedade do credenciamento de laboratórios que prestam serviços ambientais junto ao Instituto de Meio Ambiente de Mato Grosso do Sul IMASUL e estabelece as instruções gerais, procedimentos e critérios técnicos para esse credenciamento. Campo Grande, MS, 2015b.

MINISTÉRIO DO MEIO AMBIENTE MMA. Diagnóstico hidrogeológico do estado de Mato Grosso do Sul. Campo Grande, MS, 66 p., 2008.

PAULI, A. R.; QUIÑONES, F. R. E.; PALÁCIO, S. M.; MARIN, P.; OLIVEIRA, S. P.

D.; COLOMBO, A. Avaliação da qualidade da água subterrânea utilizada para consumo humano na região rural do 
munícipio de Toledo-PR. In: Congresso Brasileiro de Águas Subterrâneas, Anais [...] São Paulo: [s. n.], 2014.

PLANURB. Plano diretor de desenvolvimento urbano ambiental de Campo Grande. Campo Grande, MS, 2017.

SANTOS, A. C. Hidrogeologia: conceitos e aplicações. 3ed. Rio de Janeiro: CPRM; Recife: LABHID, 812 p., 2008.

TAHAL CONSULTING ENGINEERS LTD. Empresa de saneamento de Mato Grosso do Sul S.A. - SANESUL. Estudos
Hidrogeológicos de Mato Grosso do Sul Relatório Final. Campo Grande, 736 p., 1998.

UECHI, D. A.; GABAS, S.G; LASTORIA, G. Análise de metais pesados no Sistema Aquífero Bauru em Mato Grosso do Sul. Engenharia Sanitária e Ambiental, v. 22, n. 1, p. 155-167, 2017.

VARNIER, C.; IRITANI, M. A.; VIOTTI, M.; ODA, G. H.; FERREIRA, L. M. R. Nitrato nas águas subterrâneas do Sistema Aquífero Bauru, área urbana do município de Marília (SP). Revista do Instituto Geológico, v. 31, n. 1-2, p. 1-21, 2010. 